\title{
Polemics investigated in a late fifteenth-century Fastnachtspiel (Shrovetide play)
}

\author{
Claudia Daiber*
}

The article analyses the polemics used in the Fastnachtspiel (Shrovetide Play) Der Juden Messias - in scholarship also known as Spil vom Herzog von Burgund - by the meistersinger Hans Folz (1435/40-1513), a barber-surgeon from Nuremberg. The play belongs to a group of Shrovetide plays within Folz's oeuvre which, under a religious cover, negotiates the given sociological divide in the city of Nuremberg between the Christian and the Jewish communities at the end of the fifteenth century. In its first part, the play systematically stabilizes the Christian side and destabilizes the other, i.e. the Jewish side by directing polemical attacks through the devices of self-accusation and self-flagellation by the Jewish characters. The effect is that the actions of the Christian side are legitimized and any moral hurdles towards condemning the Jewish characters are removed by ultimately equating them with feces and swine.

The second part contains a rather ambiguous message since on the one hand the ruler expressis verbis gives his permission to the mob, represented by the jester characters, to rob, rape and oust the Jewish characters. This consenting, on the other hand, prompts a uniting of the mob characters with the ruler. In other words, any moral authority of the ruler - who clearly is a metaphor for the later emperor Maximilian I - is put on a par with the mob and is therefore denied. Whether or not this latter message was appreciated by the city council of Nuremberg at the time remains an open question since there is, to date, no archival proof of the play's staging nor of its rejection.

Keywords: City of Nuremberg; sixteenth century city culture; Fastnachtspiel/Shrovetide Play; Anti-Judaistic polemics and agitation; criticizing the ruler; staging the Judensau

* Correspondence details: Claudia Daiber, University of Groningen, PO Box 72, 9700 AB Groningen, the Netherlands. Email: c.m.daiber@rug.nl. 


\section{Introduction}

This article rethinks the polemics used against »the Jews « in the drama text Der Juden Messias ${ }^{1}$ by the Nuremberg-based Meistersinger Hans Folz (1435/1440-1513). Folz, a barber-surgeon by profession, wrote strophes in the Meistersinger tone, obscene verses (mæren), and various other sorts of text in addition to his Shrovetide plays. ${ }^{2}$ Altogether, he left a rather comprehensive oeuvre which marks him as one of the most productive authors from the Germanspeaking lands on the threshold between the Late Middle Ages and the Early Modern Period.

A characteristic of his work is that his texts are not prudish in the choice of their words, the composition of their expressions, their performativity, or their messages. This observation, however, is not unique to Folz's work. It is a common feature of the genres he is most associated with, and it is an observation that can also be made with respect to comparable works by his contemporaries. Still, these features suggest that polemical attacks lie in wait. As a matter of course, polemics in the Western world have been employed since the times of the Greek polis, where they were understood to be part of rhetoric and therefore public political speech. ${ }^{3}$ Polemics continued to be used within patristic literature, which was greatly concerned with the constitution of the Christian church and therefore with its demarcation from pagan ${ }^{4}$ and heretic beliefs and also from the Jewish belief. ${ }^{5}$ Within this context, polemics were wielded as a weapon to attack those of other faiths, but were also used in order to unite Christians against an imagined enemy. It is a well-researched historical fact that throughout Europe, anti-Judaistic and even anti-Semitic resentment increased at the end of the Late Middle Ages ${ }^{6}$ and so did anti-Judaistic polemics. ${ }^{7}$ This phenomenon can, amongst others, be traced in the religious play, and particularly in the passion play, a widespread medium in the German-speaking lands during the fifteenth and early sixteenth centuries. ${ }^{8}$ That Folz was familiar with this genre and its anti-Jewish apologetics and polemics can be assumed not only on the grounds of his general participation in this contemporary discourse but also because he makes an explicit statement to that effect in his Fastnachtspiel entitled Kaiser Constantinus. ${ }^{9}$ As he states in the play's epilogue: Und habe euch drum ein geistlichs gemacht..$^{10}$ With this statement he expresses his intention of having composed a "religious « Fastnachtspiel, an intention which he realized in three plays, one of which is Der Juden Messias, the object of investigation of this analysis.

1 The play will be referred to in this analysis with this title; another title referring to the same play more commonly used in scholarship is Spil vom Herzog von Burgund. The reason for this choice is that the play will be quoted first according to the edition Der Juden Messias, ed. Przybilski. In addition, quotes will refer to the still-used outdated edition ein spil von dem herzogen von Burgund, ed. von Keller.

2 Janota, Folz, 770.

3 Stauffer, Polemik, 1405.

4 The term "pagan« derives from the Latin word paganus which literarily means someone living in the countryside. During the fourth century, when Christianization took place within the Roman Empire due to the Constantinian shift, the term referred exclusively to persons neither adhering to the Jewish nor to the Christian faith.

5 Stauffer, Polemik, 1406 and for an analysis of polemical attacks against each group, see Opelt, Polemik in der christlichen lateinischen Literatur, 208-228.

6 See Ben-Sasson, Middle Ages, 574-592.

7 See, for example, Mittlmeier, Publizistik im Dienste antijüdischer Polemik, 101-133.

8 See Rommel, Judenfeindliche Vorstellungen, map no. 14 (without page numbering).

9 Janota, Folz, 780.

10 Janota, Folz, 780. 
The genre of the Fastnachtspiel is the representation of the profane drama of the Late Middle Ages and the Early Modern Period in the German speaking lands, and Nuremberg was one of the spots where such a literary tradition established itself. ${ }^{11}$ Besides Folz, we know two further major names in this tradition of "craftsmen-poets « hailing from the city of Nuremberg: Hans Rosenplüt (1400-60) ${ }^{12}$ and Hans Sachs (1486-1576). ${ }^{13}$ Since craftsmanship as the primary means to earn one's livelihood only existed within cities, this tradition could only develop within a city culture.

Already, this tentative sketch shows that polemical language is neither restricted to a certain form nor medium nor field, but is purpose-driven. Additionally, the sketch displays the obvious: that polemics are embedded in historical circumstances. Therefore, the analysis will not only investigate the nature, manner and direction of the attacks launched by the play, but will also connect them, where this can be substantiated, with findings by historical science.

Furthermore, an analysis of which dynamics of the text can be grasped at the interface between text and recipient will be undertaken. This approach is based on the notion that a performative text contains an inherent program as to how it is to be received. In other words, a performative text directs and constitutes its own reception and - if it is successful in doing so - constitutes realities in collaboration with its imagined historical recipients. ${ }^{14}$ In particular, when researching the emotions evoked by the text, both the play's inherent program and the constituting of possible realities at the interface with the "recipient ", will be investigated since they are both pivotal in the construction of the Self and the Other, which again is decisive in the workings of polemics.

Although this approach of unlocking the knowledge contained in the performativity of the text basically functions without the actual historical recipient, it still triggers the question of whether the play underwent a historical performance or was otherwise received. To date, archival proof that this specific play has been performed in the city of Nuremberg or elsewhere does not exist. In the Wolfenbüttel manuscript which is relevant for its dating, ${ }^{15}$ the play's title ${ }^{16}$ reads Von dem hertzog von Burguny von der juden messias vnd wie jn Sibilla vertrib kurtzweylig zuo hören. ${ }^{17}$ The opening scene of the play elaborates further on this title when it explains the play's purpose and its fictitious occasion, which is to entertain the young Duke of Burgundy, the son of the Roman King Maximilian, on his visit to Nuremberg during the carnival season..$^{18}$ To assume, based on this reference in the text, that the play was in fact performed during a visit in $1491^{19}$ by the then German-Roman King Maximilian is,

11 Wuttke, Nachwort 441 and 451-452.

12 Glier, Rosenplüt.

13 Könneker, Hans Sachs, 60-69.

14 For both forms of performativity, see Velten, Performativitätsforschung, 552.

15 See Przybilski, Anhang 194, with reference to: Wolfenbüttel, Herzog August Bibliothek, Cod. Guelf. 18.12. Aug. 4.

16 See Der Juden Messias, ed. Przybilski, 85 at no. 1.

17 "Of the Duke of Burgundy, of the Jews' Messiah and how ১Sibilla chased him out, an entertaining play« (translated by the author).

18 [...] Das der jung herzog von Burgun, / Des romischen konigs Maximilian sun / Vnser genedigster herr, itz kumpt, / [...] / die vasnacht hynn bey euch zu sein [...]. Der Juden Messias, ed. Przybilski : 1. 8-10, 12; Ein spil von dem herzogen von Burgund, ed. von Keller, 1. 9-11, 13, p. 177.

19 The actual occasion for Maximilian's stay in 1491 in Nuremberg was the coming together of the Imperial Diet (Reichstag). 
however, problematic..$^{20}$ Still, this reference is decisive when dating the play's date of origin, between 1486, when Maximilian received the title of German-Roman King, and 1493, the final date of the manuscript.

\section{The conviction of the Jewish messiah and his trial}

The play Der Juden Messias contains various scenes negotiating different topics that are all connected to one story, which is the Duke of Burgundy's encounter with the "Jews" in the city of Nuremberg, including their Messiah who is revealed as a representation of the Antichrist. This observation already marks the play's complex structure and distinguishes it from the more simple form of the Fastnachtspiel, which was a serial play ${ }^{21}$ common during the fifteenth century. In this type of play the individual scenes did not necessarily connect to a narrative whole, but were connected through a meta-theme such as amour, martial conflict, or swindle.

To reveal the narrative whole, i.e. the plot and the accompanying discourses, what follows is the analysis of the topics in their chronological order.

\section{The hegemonic claim to space}

The first entry belongs to the male jester who - in the established style for this type of play - requests attention. The second entry belongs to the herald who declares what the play's occasion is - in this case, the visiting of the city during the carnival season by the "young Duke of Burgundy ", who is a character in the play. ${ }^{22}$ Both the herald and the jester mark the beginning of the play and therefore the enactment of its fictitious world. The character of the jester additionally indicates the arrival of the carnival season.

The next entry introduces the female prophet "Sibilla «, ${ }^{23}$ accompanied by her virgins and a female jester. The Duke recognizes the extraordinariness of her appearance and therefore inquires about it. She informs him that Jewish rabbis are spreading the word that their Messiah has appeared ready to take over the world's supremacy from the Christians, and therefore ultimately from the Duke. However, within the same scene, "Sibilla" reassures the Duke that she is unable to observe such a change of the world order in the celestial movements and that the Jewish rabbis are therefore telling lies, which she will make obvious.

20 For details, see Wenzel, "Do worden die Judden alle geschant«, 237-238. It may be of interest within this context that Folz wrote a poem (Spruch) about this stay by Maximilian in Nuremberg (see Janota, Folz, 788). In this poem he describes the visit with a gesture of praise, stating, however, upfront that he was not a witness of this event and that he relied on a printed source when composing his poem with the title Von der collacio vnsers aller gnedigiste hern vn romische kunigs maximilia in nureperg zu gericht (see Hans Folz, Reimpaarsprüche, ed. Fischer, XXIX). He describes in this poem, amongst other things, a Fastnachtspiel which was obviously performed during Maximilian's stay (see Hans Folz, Reimpaarsprüche, ed. Fischer, 326, 1. 271-307). His description and therefore the content of this Fastnachtspiel do not coincide with Der Juden Messias. Its plot was obviously the traditional motive of amour. It may be assumed that Folz, business-minded and eager for glory as he was, would have mentioned the performance of his Fastnachtspiel.

21 See Wuttke, Nachwort, 444 who uses the term »Reihenspiel«.

22 See Wuttke, Nachwort , 444 and at Velten, Performativitätsforschung, 552.

23 See Przybilski, Kommentar, 161 on the reception of Sibylline literature. 
This staging ${ }^{24}$ lays down one of the major discourses of the play, which is the Jewish characters' potential to form a threat to the existing Christian order and, therefore, in particular to the Duke, who is a representative of that order, but also that they - the "Jews" - are doomed to fail.

After "Sibilla" ['s] reassurance - which is underpinned by a claim of truth - a group of Jewish characters appears, including the »Messias«; three »Rabi«[s]; and a fourth, probably not very favorable looking character labeled »Schallat Jud « ${ }^{25}$. The latter speaks up first, followed by one of the three rabbis:

\section{Weicht auß, tret vmbe vnd ruckt von stat! [...] \\ Ir cristen, do tret an ein ort, \\ Weycht in die winkel da vnd dort \\ Vnd laßt vns auch herschen ein weil, [...] \\ Dann ruckt zusamen vnd macht weit! $!^{26}$}

Step aside [...]

you Christians stay in one spot

Move into the corners

Let us also be in command for a while [...].

Move closer together and make room.

In unmistakable terms the Jewish rabbis are requiring more space for themselves, which consequently means less space for the Christian characters. Through these utterances, the stage becomes the world conquered by the "Jews « and in this world the Christians are pushed to the corners (winkel). In other words, the Jewish characters are expressing a hegemonic claim and therefore control and sovereignty in the same way as it, in their view, has been exercised hitherto by the Christians.

The jester is the one character who immediately reacts to this claim by questioning it, picking up the key term for the Christians and reacting likewise in spatial terminology:

Wolst du vns all in die winkel jagen,

Ge dannen, das dich schut der rit ${ }^{27}$

You wanna push us into the corners

Bugger off right away.

24 With reference to Fischer-Lichte, Performativität, 55-56, the term "staging " [Inszenierung] is here understood to mean everything which can be fixed prior to the actual performance [Aufführung]. For example, the time, length and mode of acting; likewise appearances, space, light and text are fixed. In other words, it means within this context, everything which is can be retrieved from the play text or other historical sources without having actual knowledge about a historical performance.

25 For an explanation of this term, see: Przybilski, Kommentar, 163.

26 Cf. , Der Juden Messias, ed. Przybilski, 1. 85, 88; 1. 94-96, 1. 101; Ein spil von dem herzogen von Burgund, ed. von Keller, 1. 28, p. 171; 1. 1. 9, p. 172.

27 Cf., Der Juden Messias, ed. Przybilski, l. 104 and l. 117; Ein spil von dem herzogen von Burgund, ed. von Keller, l. 12 and 25, p. 172. 
The rhetoric by the jester already anticipates that the "Jews " will be chased away in the end, an announcement that decreases fear and theatrical tension since it already signals unmistakably the intention of the play, i.e. to secure the Christian group and to create a We.

This first aggregate of scenes evokes a threat to the existing order and stages this threat through spatial vocabulary, which suggests a corresponding spatial choreography. The emotion that is triggered is that of aggression, which is expressed by performative vocabulary on both sides. As a consequence, the hegemonic claim to power and control is intensified on both sides, equating the hegemonic Other and the religious Other simultaneously.

\section{The dragon uncovered as "Entcrist"}

The interaction between the Christian side and the Jewish side continues, with the jester as the leading character on the Christian side. Quite clearly as a reaction to the jester's brute words regarding the messianic and hegemonic claim of the Jewish side, one of the rabbi characters falls to the feet of the "Messias" and asks him for a sign to awe the people:

Laßt pald ein zeichen werden schein,

Vnd macht dem volk ein wenig forcht. ${ }^{28}$

Send a sign soon,

With which to awe the people.

This need for a sign of power and the desperation displayed by the rabbi character are indications of the creation of an atmosphere wherein Christian superiority is expressed by ridiculing and mocking the Jewish side, their Messiah as well as their claim to hegemony. In the fictitious world of the play, this sphere is strongly backed up by the aforementioned prophecies by the Sybil character that, according to the storyline and the staged choreography, are unknown to the Jewish side but are, of course, known to the recipients. Therefore, the segregation of the two groups into the Other and the We is pushed further by giving the Christian side a knowledge advantage over the Jewish side.

Upon this request by the aforementioned rabbi, a fire-spewing dragon appears:

Hie get ein trach vnd speyt feur au $\beta^{29}$

There comes a dragon and breathes fire.

From an entertainment point of view, the appearance of any dragon creature on stage is, of course, a welcome trick in any play, and in particular in a Fastnachtspiel. How does the text imagine this fire-spewing dragon? Again, the jester is the first to react to its appearance:

28 Cf. Der Juden Messias, ed. Przybilski, 1. 133-135; Ein spil von dem herzogen von Burgund, ed. von Keller, l. 9-11, p. 173.

29 Cf., Der Juden Messias, ed. Przybilski, 1.137; Ein spil von dem herzogen von Burgund, ed. von Keller, l.13, p. 173. 
Pox grint, was teufels pist dan du?

Seh einer dem schnoden merwolf $z u^{30}$

Yuck, what a poxy scab-face, what kind of devil are you?

Look at this despicable wolf from the sea.

He calls the dragon creature "a devil« and points to its ugly appearance because it has a skin with an uneven surface. ${ }^{31}$ Although the first part of the sentence may be taken as colloquial interjectional cursing, the jester denominates, or even recognizes, the dragon creature as an incarnation of the devil, hereby receiving a widespread medieval interpretation of Apocalypse 12. 9..$^{32}$ The jester's further naming of the creature as a "schnoden merwolf" is also in line with this tradition: the "merwolf" refers to a beast arising from the sea like the seven-headed beast in Apocalypse 13. 1, which is interpreted as being a symbol for the Antichrist receiving his powers from the devil who - according to this tradition - uses the incarnation of a dragon. ${ }^{33}$

Even more revealing is the adjective added to describe this creature: schnoden. This word probably has to be read as the German word schnöde, as it is most often used in the German language in the expression of der schnöde Mammon, a Biblical expression (Matthew 6. 24, Luke 16. 9-13) referring to the personification of riches and greed in the form of a false god, which, therefore, is despicable. ${ }^{34}$ Accordingly, the dragon is an abject but likewise pitiful creature, adding to the ridiculousness of the Jewish side.

The staging suggests that "Sibilla« comes to the front. She addresses the trach (dragon) directly with the deictic "you«:

Ich pewt ${ }^{35}$, dir, trach, bey Jhesus crafft,

Das von , dir nit hie wird geschafft,

Dann das $>d u$ sitlich weichest $a b$,

[...]

Dan eins bescheid mich, ob >dußr pist:

Sag, warumb heist $>$ dur der endtcrist? ${ }^{36}$

30 Cf., Der Juden Messias, ed. Przybilski, l. 138-140; Ein spil von dem herzogen von Burgund, ed. von Keller, 1. 14-15, p.173.

31 In general the word "grint « was used to denote a skin disease on the head in the form of a scab/rash most likely leading to scars and similar phenomena (see Deutsches Wörterbuch von Grimm, Keyword: grind, 2, letters a and b). In this context it means the uneven surface of the dragon's skin.

32 Emmerson, Antichrist in the Middle Ages, 22.

33 Emmerson, Antichrist in the Middle Ages, 22.

34 Seebold, Kluge Etymologisches Wörterbuch, 594 and 820.

35 Probably understood as a swearing phrase meaning: "I command you, dragon, by Jesus' own force." See for comparable contexts and a corresponding understanding: Meyer, Jacob Grimm, Deutsche Mythodologie, ed. Meyer, 499-500 and Nöcker, vil krummer urtail, 261 (Ich peut dir hie pei deim preller).

36 Cf., Der Juden Messias, ed. Przybilski, l. 142-144, 150-1; Ein spil von dem herzogen von Burgund, ed. von Keller, : l. $17-19,26$, p. 173. 
I command 'your, dragon, by the power of Jesus,

That syour will not accomplish here

Since syou are deviating

[...]

Tell me whether syour are the one:

Tell us, why do syou< call yourself »endtcrist«?

This passage, and in particular the last sentence where the trach is addressed as endtcrist, reads that the trach and the endtcrist are one and the same entity. Since the endtcrist and the "Messias" are also one entity, the text suggests that the three characters are staged by one person.

Assuming this personal union, the performative knowledge of the text reveals a heavy polemical attack since it views the Jewish Messiah as in essence being of deceit, something which is proven by the triple identity and has already been hinted at by the jester when he does not call the dragon creature what it is announced to be: a fire-spewing dragon. Rather, proleptically, he reveals it for what it is: a companion of the devil, namely the Antichrist who only aspires towards material goods, and so evokes the Christian side's emotion of disgust and disdain even more.

Antichrist traditions of the Middle Ages have styled the Antichrist as a figure mimicking and therefore parodying Christ, thus the Anti-Christ claims to be Christ but is not Christ that is his deceit. ${ }^{37}$ The text receives this tradition when the "Messias "/trach/endtcrist, in his subsequent religious dispute with "Sibilla «, tells the lie that he is descended from the lineage of David (like Christ) whereas he is, as "Sibilla" knows, from the lineage of Dan. ${ }^{38}$ When "Sibilla " further inquires about "the length of his reign" (Nu sag, wie lang wert dein gewalt ${ }^{39}$ ), he claims to rule in eternity, a pretension which is also signaled by his telling denomination endtcrist meaning - according to his own explanation - the end of Christendom. ${ }^{40}$ When "Sibilla« asks for proof regarding this assertion, he is obviously unable to provide it because one of the rabbis then steps forward and gives his and the others' lives in pledge if it is not proven that the character in question is the true Messiah.

\section{The wheel of fortune}

Following up on the earlier pledge by the Jewish rabbi, the "Messias" character suggests consulting "the wheel of fortune" (gluckßrat) $)^{41}$, in order to continue the evidence-taking procedure and thus the further pursuit of his hegemonic claim. As expected, the wheel of fortune reacts in favor of the Duke. When the Jewish side collectively recognizes that they have fallen prey to a Ifalse Messiah, they react with despair, disdain, and death threats towards their »Messias ${ }^{42}$

37 Emmerson, Antichrist in the Middle Ages, 40.

38 Emmerson, Antichrist in the Middle Ages, 46.

39 Der Juden Messias, ed. Przybilski, l. 171; Ein spil von dem herzogen von Burgund, ed. von Keller, l.15, p. 174.

40 For further explanations, see: Wenzel, »Do worden die Judden alle geschant«, 243-244.

41 Der Juden Messias, ed. Przybilski, 1. 224; Ein spil von dem herzogen von Burgund, ed. von Keller, l. 2, p. 176.

42 See, Der Juden Messias, ed. Przybilski, l. 231-252; Ein spil von dem herzogen von Burgund, ed. von Keller l. 9-30, p. 176. 
In the fictitious world of the play, however, they not only recognize their failing, but also recognize that the Christian side is in the right, in particular when the fourth rabbi character states: Sibilla, $d u$ hast recht geseit ${ }^{43}$ /, i.e.: "Sibilla, your prophecy is right."

This realization by the Jewish side marks a new way of constructing the Other. Generally, in polemics, the Other is constructed by attacking them. In this way, the Other is first identified and then - if the attack is successful - destroyed. In this scene the rabbis attack their "Messias" who, from their perspective, has become a »false« Messiah. Even more so, they expressively agree with the accusation by »Sibilla« against the Messiah character. By doing so, the rabbis transgress the border of the Christian We and are therefore no longer the Other. Since the text signals a transgression, even a surrender of the Jewish side, it is conceivable that the text would have reacted with the offer of baptism, thereby institutionalizing the transgression. Such scenes are depicted in the twelfth-century Ludus de Antichristo ${ }^{44}$ and in the fourteenth-century Frankfurt Directive Scroll ${ }^{45}$. During the Early and High Middle Ages, this possibility of baptism existed in the hope of Christian salvation for the Jewish believers. ${ }^{4}$ A weak reminiscence of this attitude can be discerned in the Fastnachtspiel Kaiser Constantinus $^{47}$ and in the Fastnachtspiel Die alt und neu ee, ${ }^{48}$ likewise belonging to the abovementioned group of the three "religious " Shrovetide plays by Folz.

As a consequence, the play continues by letting the Jewish characters concentrate on the wrongdoing of the character they have considered to be their Messiah and on the disgrace brought by him upon the Jewish community as a whole. Wenzel therefore correctly describes this scene with the term self-flagellation, an attack directed against the self, but evoked by the (here Christian) Other. ${ }^{49}$

This scene has a victorious atmosphere since the evidence is delivered. As a gesture of gratitude, the Duke passes on his jurisdiction to "Sibilla" for her uncovering of the "Messias'" treacherous and therefore false identity.

\section{The drinking competition}

Contrary to the rabbis, the Messiah character refuses to acknowledge his defeat and, therefore, the supremacy of the Duke and the prophetess "Sibilla". It is then her turn again, or rather she takes the initiative for a further challenge in the evidence procedure on whether or not the "Messias" character is the Messiah, i.e. the one to save the world and assume supremacy. She suggests that she and her virgins enter into a drinking competition with the "Messias". If he manages to hold his liquor, her side will believe that he is the »true« Messiah:

43 Der Juden Messias, ed. Przybilski, 1. 250; Ein spil von dem herzogen von Burgund, ed. von Keller, l. 27 , p. 176.

44 Ludus de Antichristo, trans. Engelsing, 1. 361-371.

45 Janota, Frankfurter Dirigierrolle, 1. 368-9.

46 Müller, Geschichte der Juden in Nürnberg, 35.

47 Kaiser constantinus, ed. von Keller,796-819.

48 Ein vasnachtsspil ed. von Keller, 1-33.

49 Wenzel, »Do worden die Judden alle geschant«, 246. 
Es sei dann, das du trinkest mit mir

Eins wein $\beta$, den ich selbs trincken thu

[...]

Vermagst du dann auß eigner krafft,

Das es kein schaden an dir schafft,

So woll wir all gelauben das,

Du seist der warhaft Messias ${ }^{50}$

Provided that you drink with me

Wine which I drink myself, too

$[\ldots]$

Are you then able to show on your own

that it does not harm you,

we shall believe

that you are the true Messiah.

This scene, like the previous wheel of fortune scene, presents its evidence by a judgment which is a persiflage to divine judgments, from which city law at the end of the sixteenth century had long since emancipated itself. ${ }^{51}$ When viewed as a valid evidence-taking procedure, the drinking contest is an attack against the Jewish population since they were exempt from evidence by divine ordeal since Frederick II, ${ }^{52}$ or to put it differently: they did not have to swear by referring to the Christian God.

More than this aspect however, the scene connects to the (surviving) popular custom of drinking someone under the table, which has, of course, a great staging potential. Since a significant feature of the genre is the reversal of hierarchies, the play at this point seems to break through a gender pattern, i.e. that a woman invites a male person to enter into a drinking contest with her, which is a challenge to his masculinity, and - in the event of losing - a denial thereof. As expected, the »Messias « character falls drunken and bloated to the ground:

Messias trinckt, laufft vnd geschwilt vnd fellt hin. ${ }^{53}$

Messias drinks, walks and bloats and falls down.

The competition is won by "Sibilla", something which has to be imagined as a highly entertaining performance. It is, however, questionable whether "Sibilla« is therefore raised to a higher, or even male, standard at any point; conversely, it rather seems that the Jewish "Messias" character is further lowered, i.e. even below women. A further potential for laughter is to see the "Messias" - who is supposed to be the savior of the Jewish community and the future ruler of the world - inebriated and out of control in every way. It is a state with

50 Der Juden Messias, ed. Przybilski, 1. 280, 283-286; Ein spil von dem herzogen von Burgund, ed. von Keller, 1. 28-9, 31-34 p.177.

51 Nottarp, Gottesurteilstudien, 192-194.

52 Nottarp, Gottesurteilstudien, 194. In 1236 Frederick II expanded the Worms Privilege, according to which the Jewish population within the Empire could deliver evidence in legal proceedings only by oath or witnesses, thus excluding divine ordeal.

53 Der Juden Messias, ed. Przybilski, 1. 303; Ein spil von dem herzogen von Burgund, ed. von Keller 1. 17, p. 178. 
which the Christian Messiah - who within the play's paradigm is the mental prototype - is never associated, and therefore proves moreover that this character is a false Messiah. In addition, the drunk and false "Messias « character ridicules the Jewish community even more when compared with the rather serious insight the Jewish rabbis show with respect to this defeat, which they have appropriated beforehand as their defeat. Accordingly, they react by displaying vicarious embarrassment:

ann ewig muß wir uns forder schamen ${ }^{54}$

For eternity we have to be ashamed for you.

The expression of shame is pivotal for further aligning the perspective of the play towards the self-flagellation of the Other, a rather subtle technique of attacking the Other and further evoking the emotion of superiority with the in-group.

Quite fittingly, as a reaction to the drinking behavior of the "Messias " character, the female jester introduces the word sau (female swine) for the first time into the play: So, saw, so fass gar au $\beta !^{55}$ The jester utters that he would have preferred it if the false Messiah were to be hanged beyond the city walls: $D u$ werst mir lieber am galgen dau $\beta^{56}$. Again, they are anticipating things to come.

The reawakening of the false "Messias" and his confession

Following up on the jester's speech expressing discontent, "Sibilla" asks the Duke's permission to make the false "Messias « reawaken to prevent him from escaping and to definitively label him as "Endecrist ${ }^{57}$

Sibilla dicit Fursten

Herr, ob ich mit im wurcken thu

Ein genad vnd mach in wider leben,

Auff das er vns tu antwort geben,

Was in zu der pubrey bewegt,

Deucht mich nit vbel angelegt. ${ }^{58}$

Sibilla says to the Duke:

Sir, shall I act gracefully on him and make him alive again.

So that he answers what was his motivation for this roguishness

This seems a good plan to me.

54 Der Juden Messias, ed. Przybilski, 1. 318; Ein spil von dem herzogen von Burgund, ed. von Keller, l. 31, p. 178.

55 Der Juden Messias, ed. Przybilski, l. 305; Ein spil von dem herzogen von Burgund, ed. von Keller, l. 18, p. 178.

56 Der Juden Messias, ed. Przybilski, l. 307; Ein spil von dem herzogen von Burgund, ed. von Keller, 1. 20, p. 178.

57 Der Juden Messias, ed. Przybilski, l. 342; Ein spil von dem herzogen von Burgund, ed. von Keller, l. 23, p. 179.

58 Der Juden Messias, ed. Przybilski, l. 326-331; Ein spil von dem herzogen von Burgund, ed. von Keller, l. 8-12, p. 179. 
This act by the prophetess may not be unproblematic to a critical mind since by doing so she blasphemously puts herself on the same level as Christ and as the Antichrist as well who, in his mimicking of Christ, is awakening the dead, too. ${ }^{59}$

What follows is a 36-line speech by the Jewish Messiah/false "Messias «/»endecrist «" wherein he confesses his (and therefore, likewise, the Jewish community's) crimes. This is a sculmination of anti-Jewish agitation in the form of self-flagellation and comprises the confession of deprivation of Christian property, murderous actions by Jewish physicians, robbery of Christian children, Jewish hate against Christians, and last but not least, usury, which is of particular relevance in the continuation of this play. ${ }^{61}$

What is the purpose of this "confession", in which the play - in the plainest way possible - processes prejudices that are all part of contemporary anti-Judaistic discourse ${ }^{62}$ In anticipating the punishment to come, this passage evokes tension and excitement from a staging perspective. From a procedural perspective, this plea of guilt is the precondition for the trial and its verdicts to come, including their execution. The self-accusation clarifies for the recipient that hate and envy ( $h a \beta$ und neit ${ }^{63}$ ) were the motivating forces behind these crimes.

Until this point, the meta-discourse of the play has been the uncovering of the deceitful nature of the Jewish Messiah, and therefore the confirmation of the Christian perspective's righteousness. Considering this, the opening sentences of the confession are of particular relevance. In these lines, the "Messias « character states that the Duke and the prophetess are forcing him with their Christian force ${ }^{64}$ to be totally transparent:

Ir zwinget mich so hart und gnau

Mit eurem cristlichen gewalt,

Das ich nichts heimlichs dahinden behalt ${ }^{65}$

You are forcing me so strongly and precisely

with your Christian force

That I cannot hide anything

59 Emmerson, Antichrist in the Middle Ages, 133 and 215.

60 Der Juden Messias, ed. Przybilski, 1. 343-352, 353-378; Ein spil von dem herzogen von Burgund, ed. von Keller, l. 1. 24-32, p. 179, 1. 1-27, p. 180.

61 See Wenzel, »Do worden die Judden alle geschant«, 246: »ein[en] Kulminationspunkt antijüdischer Agitation«.

62 For details, see Wenzel, »Do worden die Judden alle geschant«, 246-250.

63 Przybilski, Der Juden Messias, 1. 364; Ein spil von dem herzogen von Burgund, ed. von Keller, 1. 13, p. 180.

64 Here, one may think of a confession under torture because of the word gewalt (See, Der Juden Messias, ed. Przybilski, l. 345). The application of torture in order to secure a "true« confession was common in the Germanspeaking territories from the end of the twelfth century (see Schmidt, Einführung in die Geschichte der deutschen Strafrechtspflege, 91 et seq.). Schmidt also mentions that torture was applied in order to force Jewish people to "confess" and subsequently legitimized burning large numbers of them. To assume torture would, however, not coincide with the text's intention.

65 Der Juden Messias, ed. Przybilski, l. 344-346; Ein spil von dem herzogen von Burgund, ed. von Keller, l. 25-27, p. 179. 
In other words, the Christian We hears here through the mouth of the Jewish Other that they have succeeded in skewering the greatest vice of the Antichrist - his deceitful nature. ${ }^{6}$ This means that they feel legitimized to proceed.

\section{Summary of first part analysis}

The analysis of polemics up to this point has delivered the following results: the play as a whole is set up to attack the Jewish characters within its fictitious world, since they are depicted as a threat to the existing hierarchical societal order, which is perceived as a Christian order. In each scene, this threat is factually and proleptically weakened. Thus, in the end, the Christian order is confirmed and the threat of a reversed order in the form of Jewish supremacy is averted. However, at least with the confession of the "Messias " character it has become obvious that the dramatic tension of the play is not built on whether or not the restoration of the Christian side will succeed, but rather on the destruction of the Jewish characters. This destruction is not a straightforward process throughout the play, but it is set up as a self-destruction of the Jewish characters. As a result, the staging creates an atmosphere of rightfulness on the Christian side and an atmosphere of naiveté and blindness in terms of faith on the Jewish side, which connects to the historical discourse that the Jewish people are "blind « in matters of faith since they do not recognize Jesus as the true Messiah, i.e. the one prophesied in the Tanach/Old Testament.

It necessarily follows that the play pursues the othering of the Jewish group from the beginning. The text is unambiguous in depicting the Jewish characters not exclusively as the religious Other, but in characterizing them throughout as the political Other, reaching for supremacy. In two instances, however, the text weakens the process of Othering: first, when the Jewish side stresses that they only want what the Christian side has had for a long time; and secondly, when a Jewish character agrees on the righteousness of the Christian view, thus identifying himself with the Christian side. The text reacts to the first transgression by referring to the false faith of the Jewish side, but it does not react to the second, an omission which is tangible in the absence of such a reaction.

The play is, of course, designed to evoke a whole range of emotions. Hilariousness is evoked first and foremost, and is triggered by common carnival practices. Then throughout, on a semantic and on a performative level as well, the play creates emotions caused by an attitude of Christian superiority on the Christian side which is reflected on the Jewish side through the expression of rather different emotions such as hope, trust, surprise, desperation, horror, rage, envy, hate, and vicarious shame. In particular, vicarious shame is a hybrid since the Jewish side feels ashamed for the action of their "Messias". This emotion is only possible in the first place because the Jewish side views itself, at least for a moment, from the perspective of "Sibilla" - the outside perspective.

As stated earlier, the main purpose of polemics is to create a We - in other words, an in-group, irrespective of whether or not the attack on the enemy in fact works. This pivotal aspect of polemics, mediated in whichever discourse and materiality, may be the most

66 Not surprisingly, Jewish polemical literature circulating in the Early Modern Period within Europe assigns the phenomenon of deceit to the Jesus character; see Przybilski, Zwei Beispiele antichristlicher Polemik, 256. 
precarious to generate. Since the functioning of performative texts also depends on the historical recipient, the issue at stake is whether the recipient follows the direction offered by the text. ${ }^{67}$ Ultimately, the creation of the We becomes unstable when a transgression takes place. Within this part of the play, a transgression that can be picked up by the recipient is induced by the text when the fourth Rabbi expresses vicarious shame for the behavior of the Jewish Messiah character. Since the reproach that is expressed through the emotion of shaming refers exclusively to the Jewish side and is expressed exclusively by the Jewish side, the Christian side is not involved and therefore - for a moment - a historical recipient may escape the directing force of the text.

\section{The verdicts and their executions}

The punishments by the pagans

As announced repeatedly by the megaphone function of the jester and the female jester, the "Jews « have to be punished. After the "Messias« delivers the precondition for the punishment procedure by his self-accusation, the Duke lends his competence to exercise jurisdiction with a courtly gesture to "Sibilla«. However, she rejects the offer with the telling argument that exercising this power does not behoove a woman: Es zim furwaar keinem weibspild nicht. ${ }^{68}$ With this statement, the earlier observation made in the drinking competition scene is confirmed: that "Sibilla - despite all of her powers - does not challenge the gender hierarchy. Clearly, the existing gender hierarchy is instrumentalized to put the Jewish characters down by placing them below women in the societal hierarchy.

Subsequently the Duke, growing impatient, requires his master of ceremony (Hofmeister) to bring the $\operatorname{ding}^{69}$ (thing, i.e. the sentencing) to an end. Thereupon a short interlude follows, emphasizing the alienage of the Heiden (pagans) by letting them speak a $»$ foreign language ${ }^{70}$ only understood by the Hofmeister, who then assumes the role of translator. Accordingly, the Heiden sentence the Jews to the following punishments: (1) extraction of the tongue (die zung zum nack außreyssen, ${ }^{71}$ ); (2) wrapping them in flax and then setting them on fire (mit eim flach $\beta$ vmbwinden / Vnd darnach mit einem licht antzunden ${ }^{72}$ ); (3) hanging them with a stone fixed to their neck and then drowning them (in stein an die hels pinden und henken / darnach all in ein wasser senken, ${ }^{73}$ ); (4) burning them all (Er heißt sie allesamt verprennen, / Kein pessern weck kund er erkennen. ${ }^{74}$ ). Extraction of the tongue was the punishment for

67 Velten, Performativitätsforschung, 552, speaks of »functional performativity«.

68 Der Juden Messias, ed. Przybilski, l. 398; Ein spil von dem herzogen von Burgund, ed. von Keller, 1. 8, p. 181.

69 Der Juden Messias, ed. Przybilski, 1. 399; Ein spil von dem herzogen von Burgund, ed. von Keller 1. 12, p. 181.

70 Der Juden Messias, ed. Przybilski, 1. 404-405 and 1. 412-413, 1. 419-420 and 1. 432-433; Ein spil von dem herzogen von Burgund, ed. von Keller, 1. 16-17 and 1. 25-26, p. 181, 1. 4-5 and 1. 17-18, p. 182. For explanations on the words used, see Przybilski, Kommentar, 165.

71 Der Juden Messias, ed. Przybilski, l. 408; Ein spil von dem herzogen von Burgund, ed. von Keller, 1. 21, p. 181.

72 Der Juden Messias, ed. Przybilski, 1. 414; Ein spil von dem herzogen von Burgund, ed. von Keller, 1. 28-29, p. 181.

73 Der Juden Messias, ed. Przybilski, l. 422-423; Ein spil von dem herzogen von Burgund, ed. von Keller, 1. 7-8, p. 182.

74 Der Juden Messias, ed. Przybilski, 1. 435; Ein spil von dem herzogen von Burgund, ed. von Keller l. 20-21, p. 182.

medieval worlds $•$ No. 7 • 2018 • 114-136 
blasphemy, ${ }^{75}$ burning was generally applied as a punishment for sorcery and heresy ${ }^{76}$ (and was, in particular, applied in the city of Nuremberg during the pogroms of the years 1348/49), ${ }^{77}$ and hanging was the common punishment for theft. ${ }^{78}$

Considering the "judges"' status as disbelievers, the punishments referring to crimes concerning one's correct faith are conspicuous. The text gives the impression that the patterns of force generally applied to pagans are now applied by them to the Jewish characters, again with the effect of putting them on the lowest level of the societal hierarchy, i.e. in this case below the disbelievers. By doing so, the text receives a discourse that is particular to passion plays, where the pagans are depicted as being able to understand the divine nature of Jesus Christ, whereas the Jewish remain »blind« to that epiphany. The text therefore takes an apologetic view, since against that background it is justified that the pagans are ranked higher than the Jewish characters.

This passage contains a layer of subversive criticism when read deconstructively: since jurisdiction is ultimately understood as belonging to one of the pivotal competences of the ruler - which derives from the potestas of God - it appears to be a blasphemous act to pass jurisdiction on to the "Heiden" characters, who have to be understood as being Muslim. ${ }^{79}$ This may be particularly true when considering that the fall of Constantinople in 1453 and various invasions of the south-eastern borders of the Habsburg territories by Ottoman forces took place from 1473 onwards, ${ }^{80}$ and therefore coincided with the time in which the play originated (1486-1493). Moreover, Latin Christendom viewed the Muslin Ottomans as a direct threat to its very existence and this threat was interpreted as a flagellum Dei, as a punishment from God. Thus, the text mocks the Duke by having representatives of the enemy of Christianity in his entourage.

\section{Punishments by the knights}

Subsequently, the Duke's knights (»Des Fursten Ritter«) pronounce their punishments, which are amongst others: (1) that the Jews are to be raped with glowing pans (die Juden allsant arspaß - Mit einer ganz gluenden pfannen ${ }^{81}$ ); (2) that they are stripped of their clothes, fixed beneath a latrine and are shit upon daily (Ganz ploß und nacket ziehe auß, Setz ieden unter ein scheißhaus / Und ließ ein tag aus sie schmaliern/, ${ }^{82}$ ); (3) that they are given neither meat nor drink for eight days, and that they are afterwards directed to a pig's vat in which there is a latrine [...] (Man geb in acht tagen weder trank noch speis, Darnach sie uber ein

75 Schmidt, Einführung in die Geschichte der deutschen Strafrechtspflege, 62.

76 Schmidt, Einführung in die Geschichte der deutschen Strafrechtspflege, 59, 62.

77 Müller, Juden in Nürnberg, 32-33; Schmidt, Einführung in die Geschichte der deutschen Strafrechtspflege, 92.

78 Schmidt, Einführung in die Geschichte der deutschen Strafrechtspflege, 61.

79 See Przybilski, Der Juden Messias, 165. At this point it becomes clear that the text, and therefore also Folz, apply the term "Heiden « according to the excluding definition stated above, i.e. referring to persons neither adhering to the Jewish nor to the Christian faith. In this context and time the term is, therefore, in general used to designate Muslims.

80 Waugh, History of Europe, 323. Housely, Crusading and the Ottoman Threat, 64-65.

81 Der Juden Messias, ed. Przybilski, l. 448-449; Ein spil von dem herzogen von Burgund, ed. von Keller l. 4-5, p. 183.

82 Der Juden Messias, ed. Przybilski, l. 465-467; Ein spil von dem herzogen von Burgund, ed. von Keller, l. 19-24, p. 183. 
seutreck weis, Darein gericht sei ein prifet, $\left.{ }^{83}\right)$; and (4) that their hands and feet are bound together and that they are placed on the road so that everybody passing either by foot or riding may take revenge on them (in alle vire zusamen pinden, / Und setz iglichen an ein straß, / Er kum gefaren zu fuß, zu ros, / Das sich ein ieder rech an in.$^{84}$ ).

Most of these punishments involve the use of feces. If one applies the contemporary concept that the punishment has to mirror the deed, ${ }^{85}$ then the deeds of the "Jews « have to be equated with excrement. This equation is most challenging since excrement is, on the one hand, unavoidable for the human being, but on the other hand it has to be avoided on the level of materiality and also in the discourse. The ability to avoid excrement on both levels is commonly understood to be a sign of civilization and culture. Therefore, the fact that the Jewish characters are faced with these punishments means that their deeds are on the level of feces and consequently so is their culture. In other words they are uncivilized.

Furthermore, these punishments hint, if at all, only very rudimentarily at statutory crimes and their associated customs. More revealing than the punishments themselves, however, is the status of the punisher. This has to be read as a caricature of the chevalier who recovers his and his clan's honor by force, but who in reality has become a mercenary soldier or - worse earned his livelihood through robbery. Here again the text seems to ridicule Maximilian, who hired mercenary soldiers for his military operations, dubbed numerous young men knights, ${ }^{86}$ and stylized himself as a knight during his lifetime. ${ }^{87}$

The institutionalized means of this societal group for recovering its immaterial damage, i.e. its honor, was the feud. This institution was directed towards the humiliation of the enemy, usually by physically attacking his life and/or residence. From its beginning, however, this institution provided for the possibility of waiving such attacks by atonements, i.e. compensation by material goods. ${ }^{88}$ Within the context of this analysis, it may be of interest that in 1449 , a feud was declared against the city of Nuremberg by about 120 parties, a large portion of whom consisted of different ranks of nobility. ${ }^{89}$ It can be assumed that knights were involved as parties in these conflicts, which in one way or another must have been part of the public discourse in the city and therefore known to the author, Folz. Therefore, from this perspective, knights - being the opposite of the city dweller - threatened the city's livelihood when they tried to get financial gain by declaring a feud against the (wealthy) city of Nuremberg. For these reasons, Folz, who identified himself very much with the city, must have viewed "knights " as enemies of the city. This once more displays the text's disdain for the Jewish characters since they are subjected to the ordeal of the city's enemies, but additionally it may be read as expressing disdain towards the societal group of knights, which was still very present at the end of the fifteenth and beginning of the sixteenth century.

83 Der Juden Messias, ed. Przybilski, 1. 473-475; Ein spil von dem herzogen von Burgund, ed. von Keller, l. 30-31, p. 183 and l. 1, p. 184.

84 Der Juden Messias, ed. Przybilski, 1. 484-487; Ein spil von dem herzogen von Burgund, ed. von Keller, 10-13, p. 18.

85 Schmidt, Einführung in die Geschichte der deutschen Strafrechtspflege, 66.

86 Göttert, Ritter, 261, 267.

87 Göttert, Ritter, 259-266.

88 Schmidt, Einführung in die Geschichte der deutschen Strafrechtspflege, 23-24, 48.

89 See Grathoff, Fehde, (no page numbering). 
The last knight judges that the Jewish characters shall all lie beneath a mother pig ("schwein $\beta m u t e r{ }^{90}$ ) and suck its teats, and that the "Messias « character shall lie beneath the tail of the pig, devouring its feces. ${ }^{91}$

\section{The execution of the last verdict by the mob}

By incorporating a Judensau staging, i.e. the depiction of characters marked as "Jews" in close, bodily caressing contact to a sow, the play connects to a contemporary discourse which was materialized as a sculpture on both ecclesiastical and secular buildings, predominantly in the German speaking lands. ${ }^{92}$ In the case of Nuremburg, the Judensau sculpture was and is visible in the east choir of St. Sebald's church..$^{93}$

In this final instance, the Marschalk - with rather threatening rhetoric towards the Duke - requests that jurisdiction is entrusted to the jester and the female jester. ${ }^{94}$ The Duke consents to this proceeding with - again - the remark that they should hurry up..$^{95}$

The jester reacts, however, rather slowly and long-windedly to the Duke's consent:

Ach herr, du pist ein recht narr.

Erlaub mir vnd der nerrin eins [...]

Die weil sie also sawgen hie,

das wir das geltlein von in schwaissen. ${ }^{96}$

Well Duke, you are truly a jester

Permit me

While they are sucking

That we take a little money from them.

This statement, which starts by calling the Duke in an uncomplimentary way "truly a jester «, continues to criticize the Duke by stating that "he and the likes of him " (ir fursten ${ }^{97}$ ) generally promise a lot (kunt wol vil gehaißen ${ }^{98}$ ) but only give very little (Und gebt uns hindennoch ein dreck..$^{99}$ ). On these grounds, the jester suggests that he and the female jester should be given permission to take away whatever valuables the Jewish characters have on them. Accordingly, the female jester commands:

90 Der Juden Messias, ed. Przybilski, 1. 495-499; Ein spil von dem herzogen von Burgund, ed. von Keller, 1. 21-25, p. 184 .

91 Der Juden Messias, ed. Przybilski, l. 495; Ein spil von dem herzogen von Burgund, ed. von Keller, l. 21-25, p. 184.

92 See, for details, Wiedl, Laughing at the Beast. See also Shachar, Judensau, 33-42, on the dissemination of the Judensau motif during the fifteenth century in various German speaking cities, however not specifically discussing the Judensau motif in the east choir of St. Sebald's church in Nuremberg.

93 See Wiedl, Laughing at the Beast, 338 at n. 67, 344.

94 Der Juden Messias, ed. Przybilski, 1. 511-515; Ein spil von dem herzogen von Burgund, ed. von Keller, l. 6-10, p. 185 .

95 Der Juden Messias, ed. Przybilski, l. 517; Ein spil von dem herzogen von Burgund, ed. von Keller 1. 12, p. 185.

96 Der Juden Messias, ed. Przybilski, l. 519-520, 523-524; Ein spil von dem herzogen von Burgund, ed.von Keller, l. 14-15, 18-19, p. 185.

97 Der Juden Messias, ed. Przybilski, 1. 525; Ein spil von dem herzogen von Burgund, ed. von Keller, 1. 20, p. 185.

98 Der Juden Messias, ed. Przybilski, 1. 525; Ein spil von dem herzogen von Burgund, ed. von Keller 1. 20, p. 185.

99 Der Juden Messias, ed. Przybilski, 1. 526; Ein spil von dem herzogen von Burgund, ed. von Keller, 1. 21, p. 185. 
Ir gurt dan die taschen all $a b$ :

Geb yeder herauß, was er drynnen hab ! ${ }^{100}$

You take all your bags off

And hand over whatever is in there.

This passage states in rather plain language what the two jesters aspire to gain from "the chasing away" of the "Jews". Furthermore, it also gives a clue about (at least) the fantasies that were circling in the contemporary discourse of the ordinary people about the expulsion of the Jewish population. The fantasy of the two jesters about robbing the "Jews", however, does have a rather real historical aspect to it which connects to the legal status of the Jewish population: when Maximilian consented to the expulsion of the Nuremberg Jewish population in 1498 , the city eventually had to pay him 8,000 gulden ${ }^{101}$ for the immovable property that belonged to him according to the legal institution which made the Jewish people his servi camerae regis (Knechte der königlichen Kammer) ${ }^{102}$ Vice versa, this means that the movable property of the Jewish people was not bound by the institution of the Kammerknechtschaft. Therefore it seems to have been ravailabler otherwise, i.e. for illegal acquisition by non-Jewish Nuremberg city dwellers.

The fact that the city council issued decrees ${ }^{103}$ fining physical attacks against Jewish persons indicates that there was a well-founded expectation on the side of the city council that the expelled Jewish people would fall prey to robbery by the non-Jewish people of the city. This could be due to mere greed, but was also a way to escape pending debts with their Jewish creditors. ${ }^{104}$

The "execution « of the last verdict makes it blatantly clear that in the fictitious world of the play, the "Jews « were not only equated with the impure in the religious and human realm in order to vilify them in the grossest way possible ${ }^{105}$, but that the final goal was to strip them economically. The text itself delivers two arguments for the legitimization of the Christian side to do so: the first being the confession by the "Messias" in which he admits that the "Jews" have "robbed the Christians" continuously, ${ }^{106}$ thus legitimizing the diachronically present accusation of usury and also the tool of knightly self-help; the second being that »they« - referring to the Duke and the likes of him - do it as well.

100 Der Juden Messias, ed. Przybilski, l 617-618; Ein spil von dem herzogen von Burgund, ed. Von Keller, 1. 20-21, p. 188.

101 Müller, Geschichte der Juden in Nürnberg, 81-85. Toch, Austreibung der Nürnberger Juden, 2-3. 102 Müller, Geschichte der Juden in Nürnberg, 25-26. Toch, Austreibung der Nürnberger Juden, 3.

103 Müller, Geschichte der Juden in Nürnberg, 82. See alsoToch, Austreibung der Nürnberger Juden, 5, who reports armed protection of the expelled Jewish people by city servants when leaving the city.

104 See also Toch, Austreibung der Nürnberger Juden, 5.

105 For a detailed analysis, see Wenzel, »Do worden die Judden alle geschant«, 251-255.

106 Der Juden Messias, ed. Przybilski, 1. 355; Ein spil von dem herzogen von Burgund, ed. von Keller, 1. 4, p. 180: Wie vil groß guts in abgeraubt (»that much wealth we robbed from them«). 


\section{Summary of second part analysis}

The second part of the play has two levels: an overt level which further denigrates the Jewish characters by letting disputable characters, who all belong to the Duke's entourage, judge them; and a subversive level which criticizes and ridicules the Duke. The first group of "judges " are the pagans, understood to be Muslims who - within the historical context of the play - have to be viewed as characters representing Muslim Ottoman Turks. The second group of "judges " are knights of doubtful provenience who reflect the moral doubt towards their sovereign, the Duke, a character in the play who has to be understood as a metaphor or pars pro toto for the then king and later emperor Maximilian I. Whereas the meaning and purpose of the first level is rather obvious and in line with the play's first part, the second level is initially surprising but continuously present, and it results in the weakening of the Duke's moral authority. This observation is particularly confirmed when the jester states upfront that he and his female companion just do what the Duke and the likes of him also do, thus they are copying the attitude of the Duke.

Michael Toch reports that from 1471 onwards, in an attempt to combat the increasing poverty of its craftsmen city dwellers, the city council degraded the legal status of Jewish persons and, in particular, prohibited them from taking interest for money-lending. Within the time frame indicated, the clients of the Jewish money-lenders had indeed changed from previously more powerful clients to being predominantly craftsmen who needed to borrow money in order to secure their livelihood; a situation which was due to early forms of capitalism. ${ }^{107}$ This socio-economic situation may be one layer, amongst others, against which to read the actions of the jester characters.

\section{Résumé}

As stated by Dorschel, ${ }^{108}$ the ultimate goal of polemics is tto create a $>$ we $[$ [...] that excludes the group against whom the polemical attack is directed " from participating in some social fabric. Does the text succeed in doing so? The analysis demonstrates that the text manages throughout to evoke heavy negative emotions, which make an argument for an irreconcilable divide between the Jewish and the Christian side, evoking within the latter the emotion of permanent superiority based on the idea that they are the bearers of the "true « religion. ${ }^{109}$ It is proven that this divide is a construct when the text applies the technique of self-flagellation to the Jewish side, since this attitude performs the aggression of the We against the Other as the latter's own aggression, leading to their well-deserved self-destruction. The effect thereof is that any moral hurdle whatsoever on the Christian side is avoided. Only this technique allows the ultimate emotion of schadenfreude ${ }^{110}$ to be raised, which ultimately leads the staged Christian side to become violent and any historical audience to experience expulsion as a spectacle. How does the text connect to historical facts? It could be shown that the text received contemporary history regarding the city of Nuremberg, its ongoing efforts to expel its Jewish residents, and the interactions with its then relevant ruler, Maximilian.

107 Toch, Austreibung der Nürnberger Juden, 6-9.

108 Dorschel, Passions of the Intellect, 683.

109 With respect to the construction of superiority and hegemonical claims in polemical literature of Jewish provenience, see Pryzibilski, Zwei Beispiele antichristlicher Polemik, 260.

110 See also Dorschel, Passions of the Intellect, 684. 
This historical framework, however, does not explain the play's attacks leading to the dehumanization of the Jewish characters. A decisive observation is that although other work by Folz contains anti-Jewish polemics as well, the Fastnachtspiel Der Juden Messias is by far the crudest, since the polemics show what concrete actions have to be taken in order to expel the Jewish characters. These actions require the construction of a We in the way stated above by Dorschel. In other words, at a certain point the polemics in the play become agitation in the sense that they are staged to invoke concrete actions by historical recipients. An explanation for Folz's excess in this play may be his contacts with members of the Nuremberg elite ${ }^{111}$ who, at the time of the play's origin, were very much in favour of an expulsion of the Jewish residents. This conveniently coincided with Folz's own ambitions as a social climber within the societal hierarchy of Nuremberg.

Are these findings tempered by the genre of the play? The text announces itself as a play to be performed during the carnival season for entertainment purposes. This announcement, together with the play's revue structure and its brute and vicious language that stresses the obscene, are clear features of the carnival play. The play is distinguished from the genre of the Fastnachtspiel by its length, its rather large number of characters, its depiction of a self-contained story despite its revue setting, and, above all, by its total focus on the denigration of the Jewish characters. The latter feature is traditionally present in the religious play, and specifically in the passion plays of the fifteenth and sixteenth centuries from the German speaking lands. Additionally, the play at hand introduces further motives that are typical for the passion play, for example the extensive elaboration on the blindness of the Jewish characters in matters of faith, as well as the motive of gluttony and, by extension, usury. These observations coincide with the declared motivation of its author, Folz, to elevate the Fastnachtspiel to the level of the religious play. ${ }^{112}$

The play is divided in a recognizable manner, with two major parts. It could finish with the confession of the character "Messias", representing the Jewish false Messiah, which is the final scene in the first part. But instead the play reaches its overall peak in its second part, in the Judensau scene. This staging and the intensity of the Judensau scene on an emotional and imagined physical level are a vital reminiscence of the crucifixion scene in the passion play. Both scenes are the climax of an irreversible development, and both cater to violently colored thrill and sensation, and, therefore, in essence trigger identical emotions. Any passion play, however, is driven by the intention to idealize the emotions of the Christian side in order to elevate them; Der Juden Messias is driven by the intention to dehumanize the emotions of the Jewish side in order to trigger the Christian side's nefariousness but, as a reflex, also to justify this emotion on the Christian side. This latter observation moves Der Juden Messias closer to the genre of the passion play than to that of the Fastnachtspiel.

111 Janota, Folz, 780. See also Przybilski, Kommentar, 163.

112 Janota, Folz, 779-780. Wenzel, »Do worden die Judden alle geschant«, 197. 
How is the second part of the play to be positioned? As the analyses demonstrated, the text criticizes the Duke - in this context understood as a metaphor for Maximilian and his politics - throughout the second part of the play, which is a form of "Hoheitskritik « ${ }^{113}$ This subversive carnevalesque layer of the text becomes overt when the male jester openly requests from the Duke permission to do "what he and the likes of him « do. In this instance the jester fulfills his true function, i.e. to mirror the world, thereby mocking the Duke as being a jester himself. Mocking somebody serves to denigrate the person; its opposite is to praise somebody in earnest, which the jester never does. Rather, precisely by mocking, he connects to the Duke, thereby establishing a We with him. Of course this We sheds light on the moral standing of the Duke.

The Roman-German reigning king, Maximilian, did not consent immediately to the request from Nuremberg city council to expel the Jewish population. ${ }^{114}$ Nevertheless, it is an open question whether or not the city council was pleased by a Fastnachtspiel containing such a rough and obscene criticism of the ruler, not only with respect to his reluctance towards an expulsion of the Jewish population but also with respect to the doubtful composition of his entourage which crystallized in the second part of the analysis. One may, however, assume that any historical recipient, including Maximilian himself, recognized the subversive layer, an aspect that may suggest that the play was too sensitive to be performed on the historical occasion of the ruler's visit to Nuremberg regardless of carnival traditions. This assumption is supported by the Spruch Folz wrote in the year of Maximilian's visit cited above, which mentions the live performance of a Fastnachtspiel in order to entertain the ruler and the people but not the performance of his Fastnachtspiel. ${ }^{115}$

113 Biehl, Zur Narrenfigur im `Salomon und Markolf^, 23, at n. 108.

114 Müller, Juden in Nürnberg, 81.

115 According to a poem (Spruch) written by Folz on the occasion of Maximilian's stay in Nuremberg in 1491, a Fastnachtspiel was performed. The conclusion is therefore that it was not his. 


\section{References}

\section{Manuscripts}

Von dem Hertzog von Burgundy von der juden messias vnd wie jn Sibilla vertrib kurtzweylig zuo hören, Wolfenbüttel, Herzog August Bibliothek, Cod. Guelf. 18.12. Aug. 4.

Ein vasnachtsspil, die alt und neu ee, die sinagog, von uberwindung der Juden in ir Talmut etc., Wolfenbüttel, Herzog August Bibliothek, Cod. Guelf. 18.12. Aug. 4.

Der Juden und Christen streit vor kaiser Constantinus, ein fasnachtspil. München, Bayerische Staatsbibliothek, Cgm 439.

\section{Primary and secondary literature}

Ben-Sasson, Haim Hillel, The Middle Ages, in: Haim Hillel Ben-Sasson (ed.), A History of the Jewish People (revised edition), (London 1977) 574-592.

Biehl, Theresia, Zur Narrenfigur im sSalomon und Markolf bilski (ed.), Studien zu ausgewählten Fastnachtspielen des Hans Folz (Wiesbaden, 2011) 1-36.

Der Juden Messias, ed. Martin Przybilski, in: Klaus Ridder and Hans-Hugo Steinhoff (eds.), Frühe Nürnberger Fastnachtspiele (Paderborn, 1998).

Deutsches Wörterbuch von Jacob und Wilhelm Grimm, University of Trier, (Trier Center for Digital Humanities 2011): kompetenzzentrum.uni-trier.de/de/projekte/der-digitalegrimm.

Dorschel, Andreas, Passions of the Intellect: A Study of Polemics, Philosophy 90 (2015) 679684.

Ein spil von dem herzogen von Burgund, ed. Adalbert von Keller, in: Adalbert von Keller (ed.), Fastnachtsspiele aus dem 15. Jahrhundert, Vol. 1 (Stuttgart 1853-1858) 169-190.

Ein vasnachtsspil, die alt und neu ee, die sinagog, von uberwindung der juden ir talmut etc., ed. Adalbert von Keller, in: Adalbert von Keller (ed.), Fastnachtsspiele aus dem 15. Jahrhundert, Vol. 1 (Stuttgart 1853-1858) 1-33.

Emmerson, Richard Kenneth, Antichrist in the Middle Ages (Manchester, 1981).

Fischer-Lichte, Erika, Performativität (revised edition), (Bielefeld, 2016).

Glier, Ingeborg, Rosenplüt, Hans, in: Kurt Ruh, Gundolf Keil, Werner Schröder, Burghart Wachinger and Franz Josef Worstbrock (eds.), Verfasserlexikon der deutschen Literatur des Mittelalters, Vol. 8 (Berlin, 1992) 195-211.

Göttert, Karl-Heinz, Die Ritter (Stuttgart, 2011).

Grathoff, Stefan, Fehde, in: Glossar historischer Fachbegriffe, digitale Bibliothek des Instituts für Geschichtliche Landeskunde an der Universität Mainz e. V., Regionalgeschichte, (Mainz 2017).

Hans Folz, Die Reimpaarsprüche, ed. Hanns Fischer (München, 1961).

Jacob Grimm. Deutsche Mythodologie [sic], ed. Elard Hugo Meyer, Vol. 3 (Berlin, 1878).

Housley, Norman, Crusading and the Ottoman Threat 1453-1505 (Oxford, 2013).

Janota, Johannes (ed.), Die Frankfurter Dirigierrolle, in: Hessische Passionsspielgruppe, Vol. 1 (Tübingen, 1997).

Janota, Johannes, Folz, Hans, in, Kurt Ruh, Gundolf Keil, Werner Schröder, Burghart Waichinger and Franz Josef Worstbrock (eds.), Verfasserlexikon der deutschen Literatur des Mittelalters Vol. 2 (Berlin, 1980) 769-793.

Kaiser Constantinus, ed. Adalbert von Keller, in: Adalbert von Keller (ed.), Fastnachtsspiele aus dem 15. Jahrhundert, Vol. 1 (Stuttgart 1853-1858) 796-819.

Könneker, Barbara, Hans Sachs (Stuttgart, 1971).

Ludus de Antichristo. Das Spiel vom Antichrist, trans. Rolf Engelsing (Stuttgart, 1968). 
Mittlmeier, Christine, Publizistik im Dienste antijüdischer Polemik (Frankfurt/Main, 2000).

Müller, Arnd, Geschichte der Juden in Nürnberg 1146-1945 (Nürnberg, 1968).

Nöcker, Rebecca, vil krummer urtail. Zur Darstellung von Juristen im frühen Nürnberger Fastnachtsspiel, in: Klaus Ridder (ed.), Weltliches Schauspiel in literarischen und kulturellen Kontexten (Tübingen, 2009) 239-284.

Opelt, Ilona, Die Polemik in der christlichen lateinischen Literatur von Tertullian bis Augustin (Heidelberg, 1980).

Nottarp, Hermann, Gottesurteilstudien (München, 1956).

Przybilski, Martin, Zwei Beispiele antichristlicher Polemik in Spätantike und Mittelalter, in: Eveline Brugger and, Birgit Wiedl (eds.), Ein Thema - zwei Perspektiven. Juden und Christen im Mittelalter und Frühneuzeit (Innsbruck, 2007) 253-268.

Przybilski, Martin, Anhang, in: Klaus Ridder and, Hans-Hugo Steinhoff (eds.), Frühe Nürnberger Fastnachtspiele (Paderborn, 1998) 171-202.

Przybilski, Martin, Kommentar, in: Klaus Ridder and, Hans-Hugo Steinhoff (eds.), Frühe Nürnberger Fastnachtspiele (Paderborn, 1998) 111-167.

Rommel, Florian, Judenfeindliche Vorstellungen im Passionsspiel des Mittelalters, in: Ursula Schulze (ed.), Juden in der deutschen Literatur des Mittelalters (Tübingen, 2002) 183-208.

Seebold, Elmar, Kluge Etymologisches Wörterbuch der deutschen Sprache (revised edition) (Berlin, 2002).

Shachar, Isaiah, The Judensau. A Medieval anti-Jewish Motif and its History (London 1974).

Schmidt, Eberhard, Einführung in die Geschichte der deutschen Strafrechtspflege (revised edition), (Göttingen, 1965).

Stauffer, Hermann, Polemik, in: Gert Ueding (ed.), Historisches Wörterbuch der Rhetorik (Tübingen, 2003).

Toch, Michael, »UMB GEMEYNS NUTY UND NOTTDURFFT WILLEN«: Obrigkeitliches und jurisdiktionelles Denken bei der Austreibung der Nürnberger Juden 1498/99, in: Michael Toch (ed.), Peasants and Jews in Medieval Germany: Studies in Cultural, Social, and Economic History (Aldershot, Hampshire, 2003) 1-21.

Velten, Hans Rudolf, Performativitätsforschung, in: Jost Schneider (ed.), Methodengeschichte der Germanistik (Berlin, 2009) 549-571.

Waugh, William Templeton, A History of Europe from 1378 to 1494 (New York, 2016).

Wenzel, Edith, "Do worden die Judden alle geschant". Rolle und Funktion der Juden in spätmittelalterlichen Spielen (München, 1992).

Wiedl, Birgit, Laughing at the Beast: The Judensau. Anti-Jewish Propaganda and Humor from the Middle Ages to the Early Modern Period, in: Albrecht Classen (ed.), Laughter in the Middle Ages and Early Modern Times: Epistemology of a Fundamental Human Behavior, its Meaning, and Consequences (Berlin, 2010) 325-364.

Wuttke, Dieter, Nachwort, in: Dieter Wuttke (ed.), Fastnachtspiele des 15. und 16. Jahrhunderts (revised edition), (Stuttgart, 2006) 401-419. 